\title{
Influence of New Ultrashort-Acting Beta-Adrenergic Blockers on Systolic Blood Pressure in Rats
}

\author{
M. FRYDRYCH, L. BARTOŠOVÁ, T. FLORIAN, J. NEČAS, L. BARTOŠÍKOVÁ, \\ J. KRČMÁR̆, P. MOKRÝ, V. BRUNCLÍK*
}

Faculty of Pharmacy, University of Veterinary and Pharmaceutical Sciences, Brno *Faculty of Veterinary Medicine, University of Veterinary and Pharmaceutical Sciences, Brno

Received January 9, 2004

Accepted June 17, 2004

\begin{abstract}
Frydrych M., L. Bartošová, T. Florian, J. Nečas, L. Bartošíková, J. Krčmář, P. Mokrý, V. Brunclík: Influence of New Ultrashort-Acting Beta-Adrenergic Blockers on Systolic Blood Pressure in Rats. Acta Vet. Brno 2004, 73: 181-185.

Three newly synthesized potential ultrashort-acting beta adrenergic blockers containing metabolically unstable ester functional groups that are easily cleft by plasma esterases were tested. In the experiment, 30 laboratory rats divided into 4 subgroups were used. Agent $42 \mathrm{Bu}$ was administered to Group $1(n=8)$, agent 43 Bu to Group $2(n=8)$, agent $44 \mathrm{Bu}$ to Group $3(n=8)$ and placebo to Group $4(n=6)$. Under general anesthesia the arteria carotis and vena jugularis were exteriorized. The arteria carotis was connected by a cannula to the machine HSE UNIPER UP 100, a universal perfusion system for isolated organs recording and converting actual values of blood pressure into graphical representation in a computer. Subsequently, 42Bu, 43Bu, 44Bu and placebo were administered into v. jugularis, and systolic blood pressure was recorded within the period of 18 minutes of their administration. All agents were administered at $2.5 \mathrm{mg} / \mathrm{kg}$ doses. The systolic blood pressure values after $42 \mathrm{Bu}, 43 \mathrm{Bu}, 44 \mathrm{Bu}$ administration were compared to those of the placebo Group. The 42Bu caused a statistically significant decrease $(p<0.05)$ in systolic blood pressure 1 minute after administration, 43Bu 1.5 minute after administration, and 44Bu 9 minutes thereafter. Statistically significant decrease of systolic blood pressure began immediately after administration of all three tested substances.

The results of our in vivo testing show that agent $44 \mathrm{Bu}$ was the most effective of all three tested agents. Its onset of action was rapid and the hypothesis of ultrashort action was confirmed.
\end{abstract}

Pharmacology, plasma esterases, ester functional group, universal perfusion system, hypotensive effect

Beta blockers are one of the main pharmacotherapeutical group in the treatment of cardiovascular diseases (Bartošíková et al. 1998; Nečas et al. 1997). They are indicated in the treatment of hypertension, portal hypertension, angina pectoris, some types of arrhythmias, idiopathic cardiac myopathy and in some non-cardiac disturbances, e.g. hyperthyroidism, glaucoma and some neurological indications (Hynie 1997). In patients dependent on the sympathetic tonus adverse reactions can appear typical of classical beta blockers, e.g. hypotension, bradycardia, heart failure, bronchospasm or peripheral vasoconstriction, whose effect can be manifested for several hours after intravenous administration (Mc Devitt 1979). For that reason, researchers have developed ultrashortacting beta blockers, whose advantage is in the immediate onset of action after administration, possibility of dose titration, very short duration of action and rapid offset of the action (Barbier et al. 1995). The ultrashort-acting beta blockers are parenteral agents that can be rapidly titrated in clinical situations where immediate beta adrenergic blockade is warranted (Frishman et al. 1998). Their efficacy has been shown in specific clinical settings, e.g. in patients with unstable angina, myocardial infarction, atrial fibrillation or flutter and supraventricular tachycardia (B arbier et al. 1995). Esmolol, the prototype drug of this class, has been approved for treatment of supraventricular 
tachyarrhythmias, but has also potential use in the treatment of patients with perioperative hypertension and acute myocardial ischemia (Frishman et al. 1998). Landiolol and flestolol are other agents in the group of ultrashort-acting beta blockers.

Three potential ultrashort-acting beta blockers with working names $42 \mathrm{Bu}, 43 \mathrm{Bu}$ and $44 \mathrm{Bu}$ have been synthesised at the Department of Chemical Drugs of the Faculty of Pharmacy of the University of Veterinary and Pharmaceutical Sciences in Brno, see Fig. 1 (Mokrý et al. 2002).

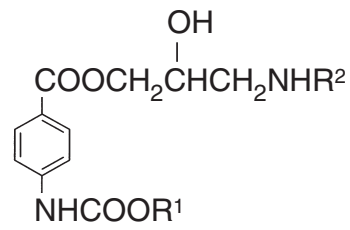

\begin{tabular}{|llll|}
\hline Agent & $\mathbf{R}^{\mathbf{1}}$ & $\mathbf{R}^{\mathbf{2}}$ & $\mathbf{M W}(\mathbf{g} / \mathbf{m o l})$ \\
\hline $42 \mathrm{Bu}$ & $\mathrm{C}_{2} \mathrm{H}_{5}$ & $\mathrm{CH}_{2}\left(\mathrm{CH}_{2}\right)_{2} \mathrm{CH}_{3}$ & 374.87 \\
\hline $43 \mathrm{Bu}$ & $\mathrm{C}_{3} \mathrm{H}_{7}$ & $\mathrm{CH}_{2}\left(\mathrm{CH}_{2}\right)_{2} \mathrm{CH}_{3}$ & 388.90 \\
\hline $44 \mathrm{Bu}$ & $\mathrm{C}_{4} \mathrm{H}_{9}$ & $\mathrm{CH}_{2}\left(\mathrm{CH}_{2}\right)_{2} \mathrm{CH}_{3}$ & 402.92 \\
\hline
\end{tabular}

Fig. 1. Chemical structures of the three tested agents

The tested agents were synthesised by 5 -step synthesis, and their structure has been verified by elementary analysis, infrared ${ }^{1} \mathrm{H}-\mathrm{NMR}$ and ${ }^{13} \mathrm{C}-\mathrm{NMR}$ spectroscopy (B artošová et al. 2002). The tested agents are chemically similar to esmolol, the prototype drug of ultrashortacting beta blockers. The extremely short duration of action of the agents was secured by the incorporation of a metabolically unstable ester functional group into their structure. The presence on the aromatic ring of a metabolically unstable ester functional group, which is very easily cleft by plasma esterases, leads to the ultrashort duration of action of the tested agents.

The aim of this in vivo testing was to monitor the influence of three newly synthesised compounds with the working names $42 \mathrm{Bu}, 43 \mathrm{Bu}$ and $44 \mathrm{Bu}$ at doses of $2.5 \mathrm{mg} / \mathrm{kg}$ of body weight on the values of systolic blood pressure of laboratory rats.

\section{Materials and Methods}

In the experiment, 30 Wistar male rats of the same age ( 60 days) and comparable body mass ( $327 \pm 25 \mathrm{~g})$ were used. The animals came from a conventional breeding colony (Faculty of Medicine, Masaryk University, Brno). They were placed in PVC cages $(\mathrm{n}=3)$, fed a standard diet (Diet for small laboratory animals SPF M1) and given water ad libitum. After 12 days of acclimatization, the animals were randomly divided into 4 groups: Group 1 ( 8 rats) was given agent 42Bu, Group 2 ( 8 rats) was given agent 43Bu, Group 3 ( 8 rats) was given agent 44Bu and Group 4 was given placebo. In general anesthesia the arteria carotis and vena jugularis were exposed and exteriorized. A. carotis was connected by a cannula to the HSE UNIPER UP - 100 device, which is a universal perfusion system for isolated organs recording and converting blood pressure values into graphical representation in a computer. Subsequently, the tested agents were administered into v. jugularis (approximately 15 min from a. carotis and v. jugularis exteriorization) as a bolus and the values of systolic blood pressure were recorded within the period of $18 \mathrm{~min}$ of their administration.

The solution for anaesthesia was administered i.m. in the femur area at a dose of $0.5 \mathrm{ml} / 100 \mathrm{~g}$ of body mass and was composed of: xylazinum (Rometar ${ }^{\circledR} 2 \%$ inj.) and ketamini hydrochloridum (Narkamon ${ }^{\circledR}$ Spofa $1 \%$ inj.) in ratio 1:20. All tested agents were administered at doses of $2.5 \mathrm{mg} / \mathrm{kg}$ of body mass as a bolus at a $1 \mathrm{ml}$ dose. As a vehicle for tested agents, a 5\% solution of dimethylsulfoxide in saline (Infusio natrii chlorati isotonica Infusia ${ }^{\circledR}$ ) was used. The placebo group was administered only $1 \mathrm{ml}$ of $5 \%$ solution of dimethylsulfoxide in saline. The experiment was always performed in the morning. First, experiment with placebo group was performed followed by the experiments with Group 1, Group 2 and Group 3, respectively.

The project was approved and monitored by the local University Ethical Committee. 


\section{Statistics}

Statistical evaluation was performed using the Microsoft Excel spreadsheet. The statistical significance of differences between the three tested groups and the placebo group was evaluated using Student's $t$-test where $p<0.05$ was considered as significant and $p<0.01$ was considered as highly significant. The obtained values of systolic blood pressure were converted to percentage changes of systolic blood pressure in relation to initial values, where initial values of $100 \%$ were assessed before administration of the tested agents (placebo).

Table 1

Values of systolic blood pressure (\%) after the administration of tested agents and placebo

\begin{tabular}{|c|c|c|c|c|}
\hline $\begin{array}{l}\text { Time } \\
\text { (min) }\end{array}$ & $42 \mathrm{Bu}$ & $43 B u$ & $44 B u$ & Placebo \\
\hline-0.5 & $100.0 \pm 0.00$ & $100.0 \pm 0.00$ & $100.0 \pm 0.00$ & $100.0 \pm 0.00$ \\
\hline 0.0 & $100.0 \pm 0.00$ & $100.0 \pm 0.00$ & $100.0 \pm 0.00$ & $100.0 \pm 0.00$ \\
\hline 0.5 & $89.7 \pm 3.81 * *$ & $91.5 \pm 2.78 * *$ & $87.1 \pm 4.11 * *$ & $96.2 \pm 2.37$ \\
\hline 1.0 & $98.0 \pm 3.40 *$ & $97.7 \pm 3.48 *$ & $86.3 \pm 5.95 * *$ & $102.5 \pm 2.16$ \\
\hline 1.5 & $102.7 \pm 3.22$ & $100.4 \pm 4.72 *$ & $85.7 \pm 5.60 * *$ & $106.5 \pm 3.12$ \\
\hline 2.0 & $105.1 \pm 3.40$ & $102.3 \pm 5.19$ & $86.1 \pm 5.69 * *$ & $108.0 \pm 4.21$ \\
\hline 2.5 & $106.1 \pm 3.27$ & $103.9 \pm 5.63$ & $86.2 \pm 6.47 * *$ & $108.3 \pm 4.73$ \\
\hline 3.0 & $106.7 \pm 3.48$ & $105.0 \pm 5.78$ & $86.5 \pm 6.83^{* *}$ & $108.1 \pm 5.13$ \\
\hline 3.5 & $106.7 \pm 3.45$ & $105.5 \pm 6.18$ & $87.9 \pm 7.08 * *$ & $108.3 \pm 5.04$ \\
\hline 4.0 & $106.8 \pm 3.32$ & $106.0 \pm 6.27$ & $88.8 \pm 8.23 * *$ & $108.3 \pm 5.04$ \\
\hline 4.5 & $106.6 \pm 3.97$ & $106.0 \pm 6.27$ & $88.9 \pm 7.75 * *$ & $108.0 \pm 5.61$ \\
\hline 5.0 & $106.4 \pm 4.20$ & $106.3 \pm 6.34$ & $90.2 \pm 8.89 * *$ & $108.0 \pm 5.61$ \\
\hline 5.5 & $106.2 \pm 4.33$ & $106.1 \pm 6.20$ & $91.7 \pm 9.19 * *$ & $108.0 \pm 5.61$ \\
\hline 6.0 & $105.7 \pm 4.23$ & $105.6 \pm 5.97$ & $92.8 \pm 10.01 * *$ & $108.0 \pm 5.61$ \\
\hline 6.5 & $105.1 \pm 4.33$ & $105.5 \pm 5.77$ & $91.5 \pm 11.77 *$ & $107.9 \pm 5.67$ \\
\hline 7.0 & $104.4 \pm 4.58$ & $104.9 \pm 5.44$ & $91.8 \pm 12.93^{*}$ & $107.4 \pm 5.81$ \\
\hline 7.5 & $104.1 \pm 4.54$ & $105.1 \pm 5.36$ & $93.3 \pm 11.17 *$ & $107.2 \pm 5.94$ \\
\hline 8.0 & $103.9 \pm 4.73$ & $104.5 \pm 5.00$ & $95.5 \pm 8.87 *$ & $106.9 \pm 5.58$ \\
\hline 8.5 & $103.7 \pm 4.69$ & $103.8 \pm 4.93$ & $97.5 \pm 6.85^{*}$ & $106.2 \pm 5.57$ \\
\hline 9.0 & $103.5 \pm 4.59$ & $103.2 \pm 4.70$ & $98.8 \pm 7.03 *$ & $105.7 \pm 5.75$ \\
\hline 9.5 & $103.5 \pm 4.40$ & $103.3 \pm 4.03$ & $99.5 \pm 7.55$ & $105.3 \pm 5.39$ \\
\hline 10.0 & $103.1 \pm 3.99$ & $103.2 \pm 4.06$ & $100.0 \pm 7.88$ & $104.5 \pm 5.25$ \\
\hline 10.5 & $103.2 \pm 3.87$ & $102.8 \pm 3.94$ & $99.8 \pm 8.01$ & $104.3 \pm 5.07$ \\
\hline 11.0 & $103.2 \pm 3.89$ & $102.5 \pm 3.90$ & $99.8 \pm 8.20$ & $104.5 \pm 5.25$ \\
\hline 11.5 & $103.1 \pm 3.78$ & $102.2 \pm 3.84$ & $99.6 \pm 8.19$ & $104.3 \pm 5.15$ \\
\hline 12.0 & $103.0 \pm 3.89$ & $101.8 \pm 3.56$ & $98.9 \pm 8.16$ & $104.3 \pm 5.15$ \\
\hline 12.5 & $103.1 \pm 4.13$ & $101.5 \pm 3.24$ & $100.6 \pm 8.42$ & $104.3 \pm 5.01$ \\
\hline 13.0 & $103.2 \pm 4.12$ & $101.0 \pm 2.78$ & $100.4 \pm 8.71$ & $104.3 \pm 5.01$ \\
\hline 13.5 & $103.3 \pm 3.99$ & $100.9 \pm 2.69$ & $100.6 \pm 8.45$ & $104.3 \pm 5.06$ \\
\hline 14.0 & $103.3 \pm 3.99$ & $100.8 \pm 2.53$ & $100.4 \pm 8.54$ & $104.3 \pm 5.06$ \\
\hline 14.5 & $103.2 \pm 3.98$ & $100.5 \pm 2.37$ & $100.5 \pm 9.15$ & $102.4 \pm 3.99$ \\
\hline 15.0 & $91.9 \pm 30.86$ & $100.4 \pm 2.59$ & $101.5 \pm 7.46$ & $104.0 \pm 4.77$ \\
\hline 15.5 & $103.1 \pm 3.98$ & $100.4 \pm 2.59$ & $101.5 \pm 7.37$ & $103.7 \pm 4.62$ \\
\hline 16.0 & $103.0 \pm 3.98$ & $100.4 \pm 2.59$ & $101.9 \pm 7.45$ & $103.6 \pm 4.52$ \\
\hline 16.5 & $102.9 \pm 4.00$ & $100.2 \pm 2.76$ & $102.0 \pm 7.46$ & $103.5 \pm 4.52$ \\
\hline 17.0 & $102.6 \pm 4.07$ & $100.1 \pm 2.64$ & $102.1 \pm 7.49$ & $103.2 \pm 4.41$ \\
\hline 17.5 & $102.6 \pm 4.04$ & $100.0 \pm 2.60$ & $102.0 \pm 7.43$ & $103.0 \pm 4.38$ \\
\hline 18.0 & $102.6 \pm 4.04$ & $100.0 \pm 2.60$ & $102.0 \pm 7.43$ & $102.8 \pm 4.25$ \\
\hline
\end{tabular}

$-0.5 \mathrm{~min}=$ time before tested agents and placebo administration

$0 \mathrm{~min}=$ time of tested agents and placebo administration

$* \quad=$ the value is significantly different at $p<0.05$ against placebo

$* * \quad=$ the value is significantly different at $p<0.01$ against placebo 


\section{Results}

The results are given in Table 1 (see previous page).

Systolic blood pressure values after placebo administration

Immediately after placebo administration there was a mild decrease of blood pressure, which was most expressive in the 0.5 min after administration - $96 \%$ of the initial value. In the following minutes there was a mild elevation of systolic blood pressure to $108 \%$, which slightly decreased to $102 \%$.

Systolic blood pressure values after a $2.5 \mathrm{mg} / \mathrm{kg}$ dose of the $42 \mathrm{Bu}$ agent administration

Agent 42Bu caused a significant $(p<0.01)$ decrease in blood systolic pressure compared to the placebo $0.5 \mathrm{~min}$ after administration. One minute after administration, $42 \mathrm{Bu}$ caused a significant decrease $(p<0.05)$. In the following minutes, $42 \mathrm{Bu}$ did not differ from the placebo.

Systolic blood pressure values after a $2.5 \mathrm{mg} / \mathrm{kg}$ dose of the $43 \mathrm{Bu}$ agent administration

Agent 43Bu caused a significant decrease $(p<0.01)$ in blood systolic pressure compared to the placebo $0.5 \mathrm{~min}$ after administration. One and a half minutes after administration, $43 \mathrm{Bu}$ caused a significant decrease $(p<0.05)$. In the following minutes, $43 \mathrm{Bu}$ did not differ from the placebo.

Systolic blood pressure values after a $2.5 \mathrm{mg} / \mathrm{kg}$ dose of the $44 \mathrm{Bu}$ agent administration

Agent 44Bu caused a significant decrease $(p<0.01)$ in blood systolic pressure compared to the placebo 6 minutes after administration. Nine minutes after administration, $44 \mathrm{Bu}$ caused a significant decrease $(p<0.05)$. In the following minutes, $44 \mathrm{Bu}$ did not differ from the placebo.

The most marked decrease of systolic blood pressure in all three tested agents appeared 1.5 min after administration (85.7\% of initial value).

\section{Discussion}

We tested in vivo three new potential ultrashort-acting beta blockers with working names $42 \mathrm{Bu}, 43 \mathrm{Bu}$ and $44 \mathrm{Bu}$. These substances belong to the group of aryloxyaminopropanole analogues. The effects of agents $42 \mathrm{Bu}$ and $43 \mathrm{Bu}$ did not markedly differ from the placebo. Only in the first minute after administration, they caused a 5-6\% stronger decline of systolic blood pressure than the placebo, and then subsequently the values of agents $42 \mathrm{Bu}$ and $43 \mathrm{Bu}$ did not significantly differ from the placebo. Agent 44Bu caused a significant decrease of systolic blood pressure lasting for 9 minutes after administration. This was the most marked and longest decrease of all the tested agents. We presume that this decrease was due to its highest lipophilicity of all the tested agents. With regard to the high lipophilicity of agent $44 \mathrm{Bu}$ and its influence upon ion membrane channels, we also assume that agent $44 \mathrm{Bu}$ contributes to a quite pronounced membrane stabilizing activity (MSA).

The longer pharmacodynamic effect of agent $44 \mathrm{Bu}$, in contrast to agents $42 \mathrm{Bu}$ and $43 \mathrm{Bu}$, is evidently due to slower washing out from the tissue and higher lipophilicity. In contrast with esmolole (Flaherty et al. 1989), whose effect starts 5 minutes after administration, all the tested agents have shown their hypotensive effect immediately after administration. The effect of esmolole fades away in 30 minutes after administration (Angaran et al. 1986; Blanski et al. 1988; Reilly et al. 1985) but agent 44Bu affected 
blood pressure 9 minutes after administration. We consider both of the above mentioned features of agent $44 \mathrm{Bu}$ - immediate effect on blood pressure and rapid fading away of its therapeutical effect - as beneficial and very promising for further laboratory in vivo testing of other pharmacodynamic and pharmacokinetic parameters of agent 44Bu.

\section{Vliv nových ultrakrátce působících beta adrenergních blokátorů na systolický krevní tlak laboratorního potkana}

V této experimentální práci byly testovány tři nově syntetizované ultrakrátce působící beta adrenergní blokátory obsahující ve své struktuře esterovou funkční skupinu, která je snadno štěpitelná plazmatickými esterázami. Testovaná skupina zvířat obsahovala 30 laboratorních potkanů rozdělených do tři podskupin. Látka $42 \mathrm{Bu}$ byla podávána první skupině ( 8 potkanů), látka 43Bu druhé skupině ( 8 potkanů), látka 44Bu třetí skupině ( 8 potkanů) a čtvrté skupině bylo podáváno placebo ( 6 potkanů). V celkové anestézii byly vypreparovány arteria carotis a vena jugularis. Arteria carotis byla připojena na přistroj HSE UNIPER UP-100, což je univerzální perfúzní systém pro izolované orgány snímající a převádějící aktuální hodnoty krevního tlaku na grafický záznam do PC. Následně byly do vena jugularis jednorázově injikovány roztoky látek 42Bu, 43Bu, 44Bu a placeba a hodnoty krevního tlaku byly snímány po dobu 18 minut od aplikace. Látky 42Bu, 43Bu a 44Bu byly aplikovány v dávce $2,5 \mathrm{mg} / \mathrm{kg}$. Zkoumané látky byly porovnány proti placebu.

Látka 42Bu zaznamenala statisticky významný rozdíl v poklesu systolického krevního tlaku po dobu 1 minuty od aplikace, látka 43Bu 1,5 minuty od aplikace a látka 44Bu 9 minut od aplikace. Statisticky významný pokles krevního tlaku nastal u všech tří testovaných sloučenin bezprostředně po aplikaci. Výsledky našeho in vivo testování ukazují, že látka 44Bu vykazuje nejvýraznější efekt ze všech tří testovaných látek. Nástup jejího účinku byl rychlý a byla potvrzena hypotéza ultrakrátkého účinku.

\section{Acknowledgement}

This work was supported by a grant of IGA VFU - IG334035.

\section{References}

ANGARAN, DM, SCHULTZ, NJ, TSCHIDA, VH 1986: Esmolol hydrochloride: an ultrashort-acting betaadrenergic blocking agent. Clin Pharm 5: 288-303

BARTOŠİKOVÁ, L, NEČAS, J, PAVLÍČEK, V, KUCHTIČKOVÁ, S, FRÁŇA, P, ZAVADILOVÁ, R, HUŠEK, K 1998: Study of the effect of the sympatolytic in the conditions of experimental alloxan diabetes in the laboratory rat. Čs a slov farm 47: 151-154

BARBIER, GH, SHETTIGAR, UR, APPUNN, DO 1995: Clinical rationale for the use of an ultra-short acting betablocker: esmolol. Int J Clin Pharmacol Ther 33: 212-218

BARTOŠOVÁ, L, FRYDRYCH, M, BARTOŠÍKOVÁ, L, MOKRÝ, P, BRUNCLÍK, V, NEČAS, J 2002: In vivo testování bradykardického účinku derivátů aryl-karbonyl-oxy-amino-propanolů. Sborník 31. konference syntézy a analýzy léčiv, Bratislava, p. 29

BLANSKI, L, LUTZ, J, LADDU, A 1988: Esmolol, the first ultra-short-acting i.v. beta blocker for use in critically ill patients. Heart Lung 17: 80-89

FLAHERTY, JF, WONG, B, La FOLETTE, G, WARNOCK, DG, HULSE, JD, GAMBERTOGLIO, JG 1989: Pharmacokinetics os esmolol and ASL-8123 in renal failure. Clin Pharmacol Ther 45: 321-327

FRISHMAN, WH, MURTHY, S, STROM, JA 1998: Ultra-short-acting beta-adrenergic blockers. Med Clin North Am 72: 359-372

HYNIE, S 1997: Farmakologie IV. Karolinum, pp. 39-41

McDEVITT, DG 1979: Adrenoceptor blocking drugs: clinical pharmacology and therapeutic use.Drugs 17: 267-288

MOKRÝ, P, CSÖLLEI, J, BARTOŠOVÁ, L, FRYDRYCH, M, NEČAS, J 2002: Syntéza a biologická aktivita derivátů [(arylkarbonyl)oxy] aminopropanolu. Sborník 31. konference syntézy a analýzy léčiv, Bratislava, p. 84

NEČAS, J, BARTOŠÍKOVÅ, L, DRÁPELOVÁ, L, HUŠEK, K, PAVLÍČEK, V, KUCHTÍČKOVÁ, Š 1997: Experimental investigation of the action of the beta-blocker carvedilol in ischemic-reperfusion renal damage. Vnitř Lék 43: 707-711

REILLY, CS, WOOD, M, KOSHAKJI, RP, WOOD, AJJ 1985: Ultra-short acting beta-blockade: a comparison with conventional beta blockade. Clin Pharmacol Ther 38: 578-585 